of Fitch and ziczac and octonotata of Walsh. The unicolorous species are querci Fitch commissuralis Stal and australis and albicans of Walsh. Rosae Harris, I think, belongs here.

There are no described species of Eupteryx in North America but I am acquainted with several undescribed.

One would expect that several American species would be the same as European but although I have compared our species with the descriptions of the European insects and have had a considerable set of European typhlocybini for comparison I have yet to find one identical.

This family is certainly a promising one for study as the literature is small and, therefore, easily obtained and a rich harvest of new species is waiting to reward the student.

\title{
NOTES ON CERTAIN CYNIPIDAE WITH DESCRIPTIONS OF NEW SPECIES.
}

BY C. P. GILletTe, AMES, IOWA.

(Concluded from p. 188.)

NEW SPECIES DESCRIBED. GALls on WHite oAK (2uercus alba). Andricus foliaformis, n. sp.

Gall. Small wart-like projections thrown out from the mid-rib on the under side of the leaves from which there grows a leafy expanse that extends on all sides like the corolla of a rotate flower. (Fig. I.)

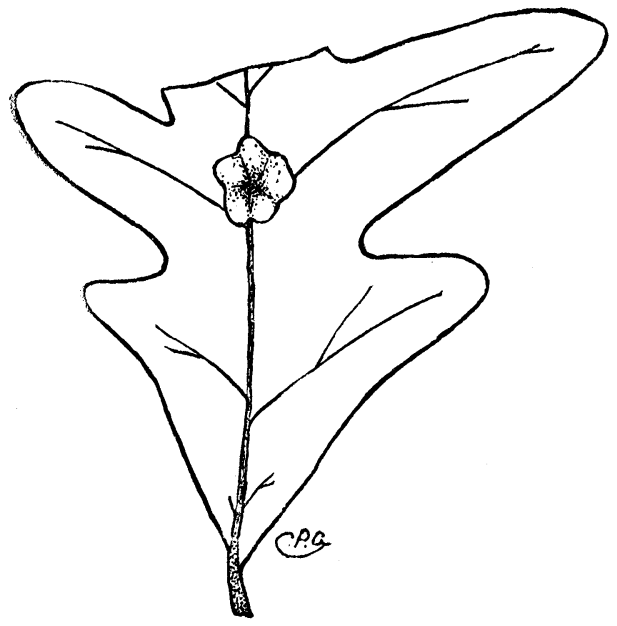

Fig. I.
Gall-fly : Female. Head, dark reddish brown with median line of face, vertex, and occiput almost black; front and genae with many short gray hairs; vertex bare. Thorax from collar twothirds of the way to the scutellum, between the parapsidal grooves, black; the remainder of the thorax brown. Parapsidal grooves distinct but not deep; outside of the grooves on either side a longitudinal patch of black is separated from the central black portion by a yellowish-brown line along either groove. Dorsal portion of thorax sparsely haired; pleurae rather densely haired; tegulae brown. Abdomen brown, smooth and shining, the darkest portion being on the posterior dorsal part. With a power of 50 diameters, minute punctures can be seen on the abdominal segments; second segment sparsely haired on sides. Scutellum with two fovae at base separated from each other by a narrow ridge; rounded behind, black at base, changing to 
brown at the tip, and thinly set with long hairs. Head, thorax and abdomen, when examined with a power of 50 diameters, have a scaled appearance. Antennae three-fourths the length of the body, I3-jointed, first and second joints stout, third joint longest, last joint nearly equal to the two preceding in length; slightly clavate and rather densely ciliated throughout; basal joints, yellowish-brown. Length of body, $\mathrm{r} .5 \mathrm{~mm}$.

Described from a single specimen that issued 30 July.

Biorhiza rubinus, n. sp.

Galls: When the leaves begin to turn in October, subglobular juicy galls about two or three $\mathrm{mm}$. in diameter and rosy in color are found attached to the under side of the leaves. From a number of these galls collected in October, '87, four were selected and opened I5 October'88, from which one fully developed female cynip and three plump white larvae were obtained.

Gall-fly: Shining black in color except the joints of the legs which are yellowish-brown. Head and thorax appear to be covered with shiny black scales. Clypeus with a number of rather stout hairs; a very few short hairs on front border of epicranium and on occiput; vertex bare. Antennae I3-jointed reaching the middle of the abdomen, first and second joints nearly equal in length and rather stout, the first somewhat stouter than the second, third joint longest and most slender, third to i 2 th gradually shortened, $13^{\text {th }}$ once and a half as long as the I2th; brown-black in color and covered with a short gray pubescence. Parapsidal grooves are shallow and indistinct, but can be traced about one-third of the way from the scutellum to the collar. Scutellum much rounded behind and with two shallow fovae at base. Abdomen a smooth glossy black. Legs rather thinly set with a gray pubescence; femora with the same scaled appearance as the head and tho$\operatorname{rax}$; thorax sparsely set with short gray hairs. Length $\mathrm{I} .5 \mathrm{~mm}$.

\section{SWAMP OAK (2uercus bicolor).}

\section{Holcaspis bassetti, n. sp.}

Gall: The gall occurs, sometimes singly, but usually in clusters about the twigs. The cluster represented at Fig 2

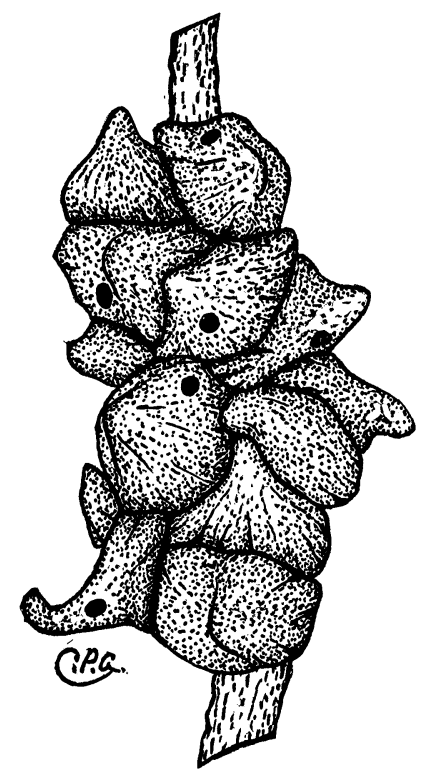

Fig. 2.

was composed of 30 of these galls closely 
crowded together. The galls resemble very much the galls of Holcaspis duricoria Bass. (Cynips mamma Wal.) (Fig. 3 ). The galls are very much the

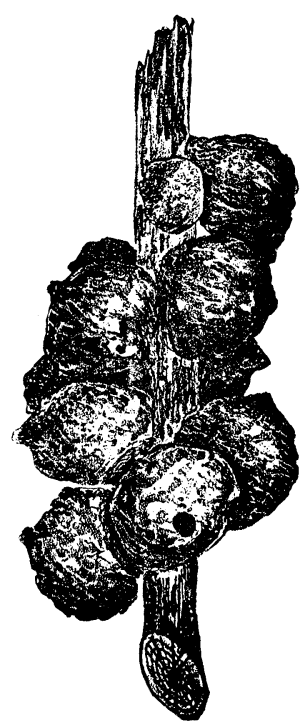

Fig. 3 .

shape that a thick waxy material would take if dropped on the twigs and then suddenly congealed, leaving stout, teatlike projections standing out from each drop. The central cell is placed low in the gall and can usually be seen protruding when the latter is broken off. Some entomologists have thought this gall to be identical with Walsh's C. mamma, but I have examined a large number of both forms and the following points of difference, which convince me that this, if not not a new species, is certainly a well marked variety:

H. bassetti as compared with $H$. duricoria, is rather larger and is more irregular in outline. The teat-like pro- jection is much heavier and longer in proportion to the size of the gall and appears to be a drawn-out portion of the substance of the gall, while in duricoria it is a small, hard pointed projection much resembling a spine in many cases, and often almost entirely wanting. In bassett $i$ the substance of the gall is more corky and easy to cut. The central cell, as before stated, is at the base of the gall, and when the latter is removed the point of the cell can usually be seen protruding below. Before the gall is detached the central cell is situated with its greatest diameter perpendicular to the limb at the point of attachment of the gall. In duricoria the cell is situated at the centre of the gall; it never protrudes from below when the gall is detached; and it always has its greatest diameter parallel with the limb at the point of attachment of the gall. The central or larval cells are also differently shaped. In duricoria the cell is egg-shaped, while in bassetti the end towards the twig is somewhat pointed, so that the cell is very much the shape of a plump apple seed with the point rounded off.

Gall-fly: Female. Median line of the face black, the black portion being broadest between the eyes; vertex dark brown to black; occiput black; orbits and genae cinnamon brown; clypeus and lower border of epicranium black; mandibles black at base and tip, with the median portion brown; palpi a light amber color, with the terminal joints of the maxillary palpi infuscate; and all joints set with gray hairs. The epicra- 
nium joining the clypeus is finely rugose. Antennæ I3-jointed; third joint the longest ; joints from 3-1 2 gradually shorter; the $3^{\text {th }}$ equal to the two preceding in length. The terminal joints, under a power of 50 diameters, appear distinctly fluted longitudinally. Color of the antennae black, except the first two joints which are brown-black. All the joints are rather thickly set with a fine pubescense. Parapsidal grooves begin midway on the thorax and extend back to the scutellum. They are very shallow and to the unaided eye appear like two narrow black lines. A little forward of the grooves two parallel black lines arise and extend forward to the collar. Near the base of the wings on either side there begins another black line that runs to the scutellum. In the two latter cases the black lines are narrow, strips of the thorax that have no hairs growing upon them. Scutellum without fovae or grooves, rounded and elevated posteriorly, covered with a yellowish brown pubescense, very irregularly rugose and black in color, except the tip, which is usually brown. Tegulae brown. Abdomen shining black with silky pubescense on the sides of the second segment. Under a power of fifty diameters the sides of the abdominal segments appear crackled or scaled and finely punctate. Wings hyaline; cross veins black and heavy; radial nervure not reaching the costal margin. Length of wing 5.2 to 5.7 $\mathrm{mm}$. Legs very dark cinnamon brown and rather thickly set with a gray pubescense. Terminal joints of tarsi black.
Length $4.2 \mathrm{~mm}$.

Described from nine specimens reared from the galls.

Cynips nigricens $\mathrm{n}$. sp.

Galls in clusters attached to the midrib on the under side of the leaves. The galls are cone-shaped, and resemble very small galls of $C$. strobilana. The galls fall to the ground a little before the leaves drop in the fall. From a large number of these galls gathered in October, I887, I obtained one perfectly developed female late in September, I888. The fly may be described as follows :

Color, except joints of legs, tarsi, and venter, black.

All parts of the insect except the dorsal portion of the first two or three abdominal segments, and compound eyes, are rather densely and evenly covered with a short gray pubescence set in minute punctures.

Head: vertex and occiput appear to be covered with minute thick scales; clypeus and front rather coarsely punctate. Antennae I3-jointed; first joint stout, third joint longest, third to seventh gradually shorter, eighth to twelfth subequal, thirteenth as long as the two preceding and with a slight indication of a division at its middle. The last five or six joints form a slight club and are fluted longitudinally. Length $2 \mathrm{~mm}$. Thorax : parapsidal grooves distinct but narrow ; widely separated at collar, and forming a double curve as they pass over the thorax to the scutellum. Two black parallel lines begin midway on the thorax between the parapsides and 
extend to the collar. Another slightly depressed line begins on either side of the thorax near the base of the wings and runs towards the scutellum. Thorax and scutellum with the same scaled appearance as the epicranium. Scutellum broad as long, obtusely rounded posteriorly and with two shallow fovae at base. Wings : areolet small and indistinct; cubital nervure rather faint; cross veins rather heavy; radial nervure not reaching the costal margin. Length, $2 \mathrm{~mm}$. Abdomen: the large second segment occupies about one-third of the abdomen; all of the segments punctured and set with many short gray hairs. Length of insect $3 \mathrm{~mm}$.

BURR OAK (2uercus macrocarpa). Acraspis villosus n. sp.

Gall : Hard globular excrescenses on the under side of the leaves and always attached to the midrib. (Fig. 4) Me-

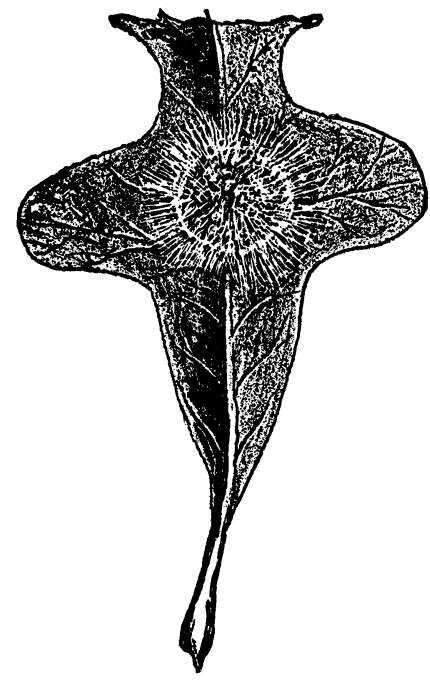

Fig. 4 . dium sized specimens measure 5-16 of an inch in diameter. The galls resemble rather closely the galls of $A$. erinaceae but differ from it by having a much heavier pubescense, by always being single-celled and by being light yellow in color.

Gall-fly: Sub apterous females only have been reared.

Head: Median line of face, including clypeus, vertex and occiput, black. Orbits and genae dark cinnamon brown. In dark specimens nearly the entire face is black. Jaws and terminal joints of palpi black. Head and mouth parts sparsely pubescent. Epicranium, bordering clypeus, rugose; remainder of head punctate. Thorax, brown, bordered anteriorly and posteriorly with black. Parapsidal grooves wanting. Thorax and scutellum punctate and finely pubescent. Abdomen thickly set with a yellowish-gray pubescence that gives a decided velvety lustre to the sides of the abdomen. The anterior dorsal portion of the second segment has a large bare spot that is continued in a narrow line back over the succeeding segments. The borders of the segments show as black rings crossing the velvety surface. Legs, brown; tarsi infuscate. Antennae I3-jointed ; third joint longest ; last joint as long as the two preceding, and all of the joints rather densely haired. Length, $4 \mathrm{~mm}$. Neuroterus nigrum n. sp.

Galls: The galls are little pimples about $2 \mathrm{~mm}$. in diameter on the surface of the leaves (Fig. 5) and show equally well from above and below. There are 
usually a large number on a single leaf. The galls appear late in August but the flies do not emerge until the following summer. Few of these galls were noticed in Michigan, but they are very common about Ames, Iowa. My specimens were reared from the leaves of the burr oak, but in a number of instances I have taken galls that seem exactly similar on the leaves of the white oak, 2. alba. scutellum was unifoveate. Scutellum broadly rounded behind; without fovae or grooves; with a very few hairs ; and with the same scaly appearance as the head and the thorax. Abdomen, shining black in color, with the ovipositor sheathes projecting. Antennae with the first and second joints very stout and sub-equal in length; third joint longest, and the last four or five joints forming a slight club. The basal joints are sparse-

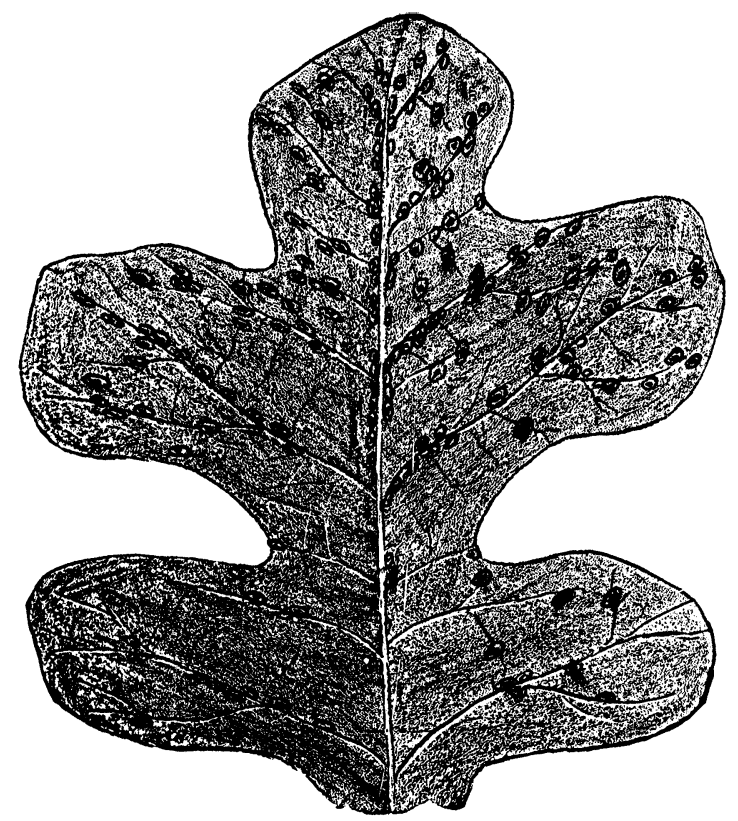

Fig. 5 .

Gall-fly : Color, except the tarsi, joints of the legs and antennae, black. Head and thorax shining and with a scaled appearance when viewed with a high power. Thorax almost entirely free from hairs and without parapsidal grooves. The meso-thorax is notched posteriorly making it appear as if the ly and the terminal joints rather thickly set with short hairs; number of joints, 13. Eyes coarse; ocelli rather obscure. Wings, hyaline; areolet large; radial nervure reaching the costal margin; marginal cell open. Length, $\mathrm{r} \cdot 3 \mathrm{~mm}$. Length of body, $\mathrm{r} \mathrm{mm}$. 
RED OAK (2uercus rubra). Amphibolips cookii n. sp.

Galls (Fig. 6) globular, with a central larval cell held in place by stout radiating fibers. When green, the galls resemble very much the growing galls of Amphibolips inanis O. S. The gall differs from that of $A$. inanis by having a thicker outer shell, by having much stouter radiating fibres, by being somewhat drawn out into a point at either extremity, and by occurring on the buds instead of the leaves. The galls fall with the leaves or before them, and, when dried, the outer surface is much shrivelled in appearance. About a pint of these galls were gathered, some late in the fall and others early in the spring, under a large red oak. On cutting into these galls the first day of September following, five fully developed flies and one pupa were found, all females.
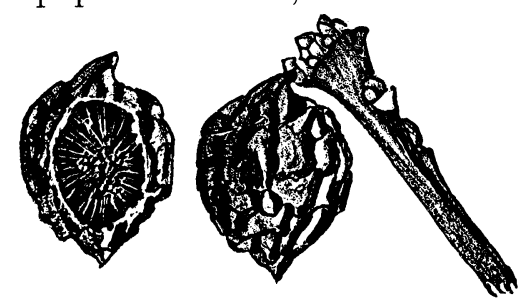

Fig. 6.

Gall-fly: Head small ; clypeus and jaws punctate; vertex, occiput, and median line of front coarsely pitted or sculptured; genae and sides of the face deeply rugose, the furrows spreading out like a fan from either side of the clypeus; entire head jet black and rather thinly set with a grayish pubescence, except on the vertex, where it is bare. Jaws black; palpi brown. Antennæ reach the middle of the abdomen; I3-jointed, third joint longest; joints $3^{-1} 2$ gradually shorter $; 3^{\text {th }}$ joint next to the third in length and as long as the IIth and I 2 th together. Thorax entirely black. Parapsidal grooves present but very indistinct and can be traced about one-third of the way from the scutellum to the collar. Between and a little in front of these grooves arise two parallel black ridges that appear as minute shiny lines which extend forward to the collar. Two other similar lines start midway on the thorax a little outside of the parapsidal grooves near the base of the wings and extend back to the scutellum. Thorax and scutellum deeply sculptured and sparsely set with short gray hairs. Scutellum with two large fovae at the base separated by a narrow septum; subquadrangular in outline and rounded and elevated posteriorly. Abdomen varies from a very dark amber to almost black; segments densely and finely punctate when examined with a power of 20 diameters; lateral portions of second segment very sparsely pubescent. Legs dark amber in color except the tips of the tarsi which are black; finely pubescent throughout; coxae black. Wings seven to eight $\mathrm{mm}$. in length; somewhat smoky, and with a large stigmal spot at the base of the marginal cell. Length of body five and one half $\mathrm{mm}$.

The following is a list of the cynipidous galls taken in the vicinity of the Michigan agricultural college. I have in each case given the variety of oak upon which they were taken, the date that the flies emerged, when reared, and the guests and parasites reared from the different species: 


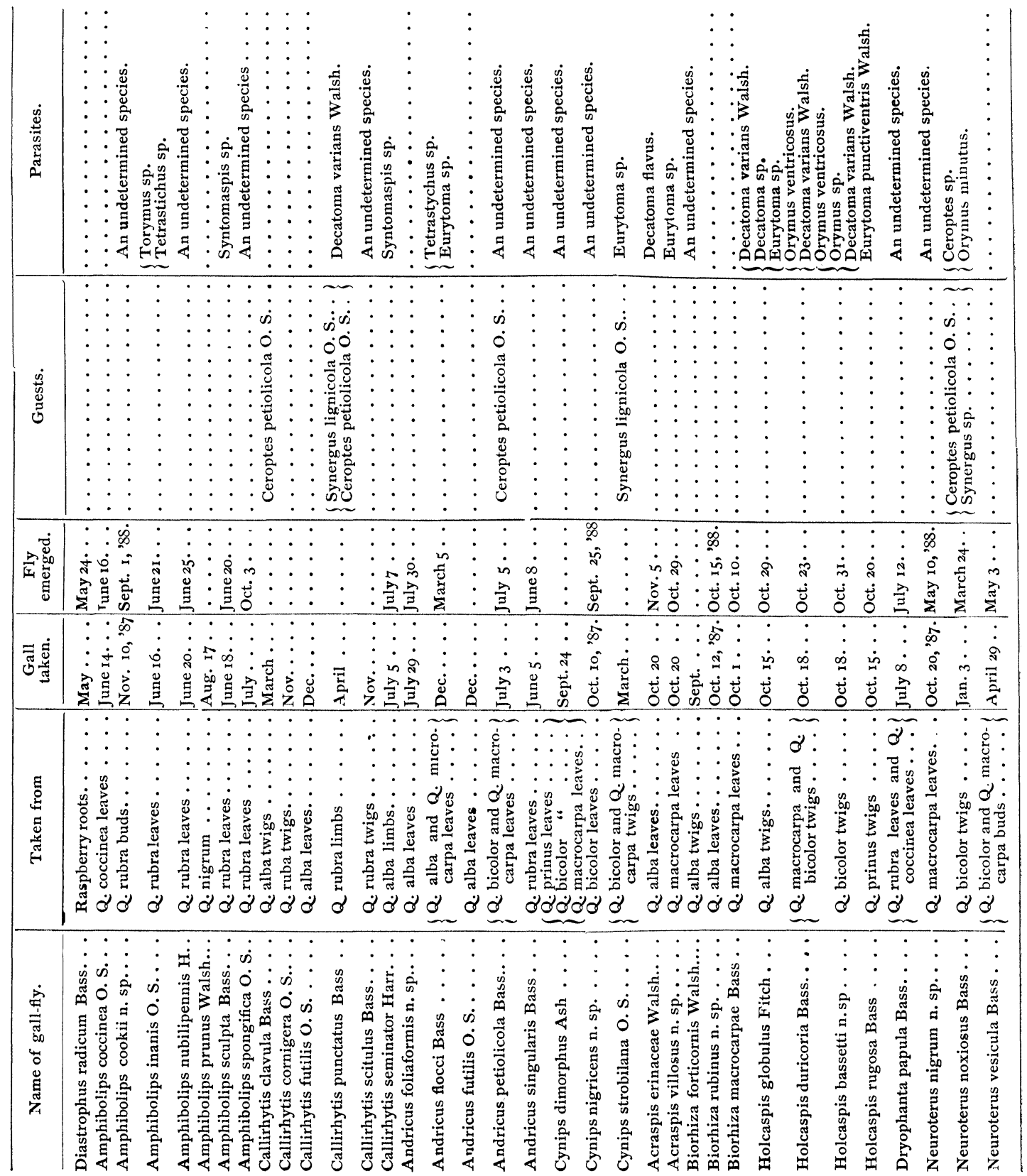



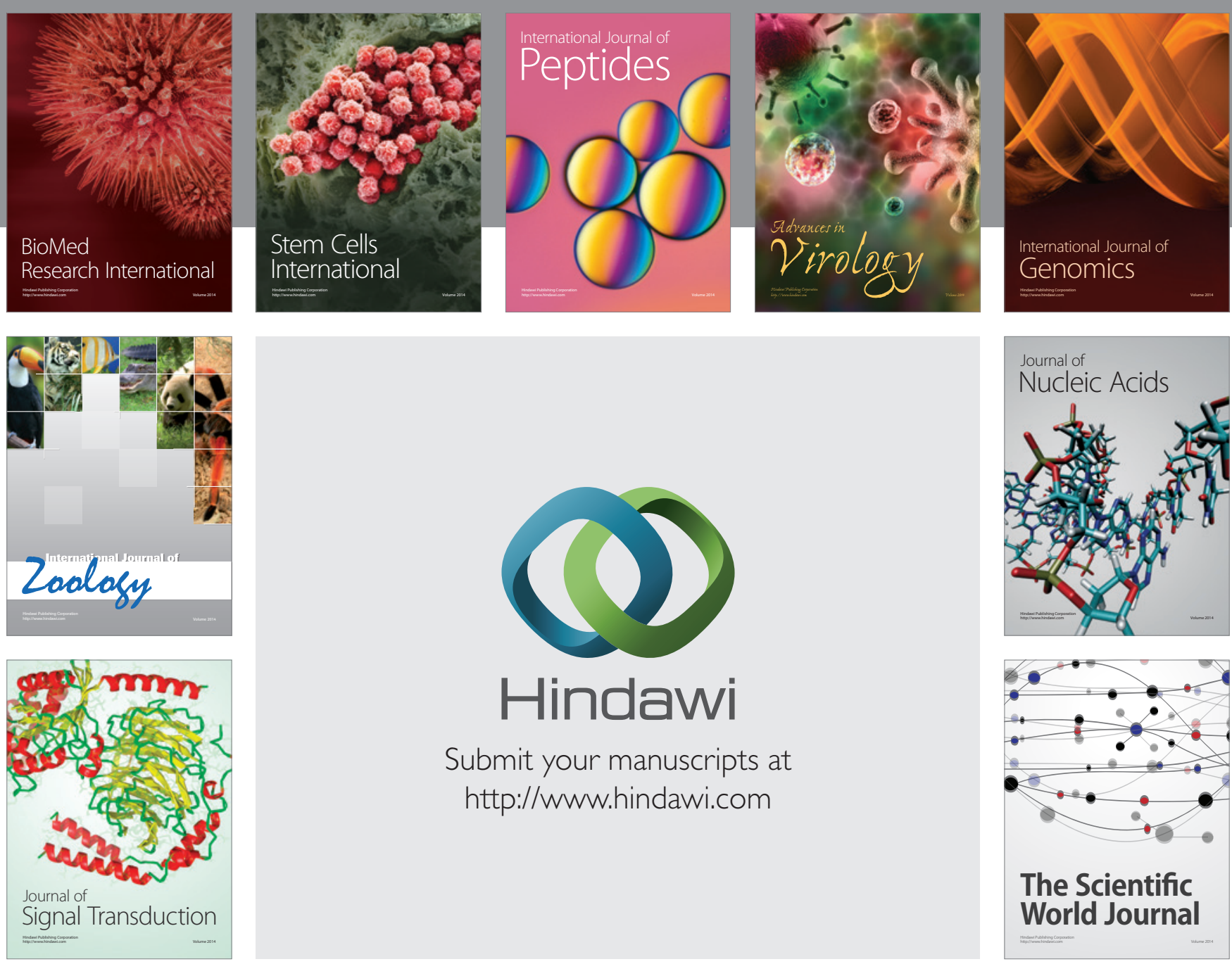

Submit your manuscripts at

http://www.hindawi.com
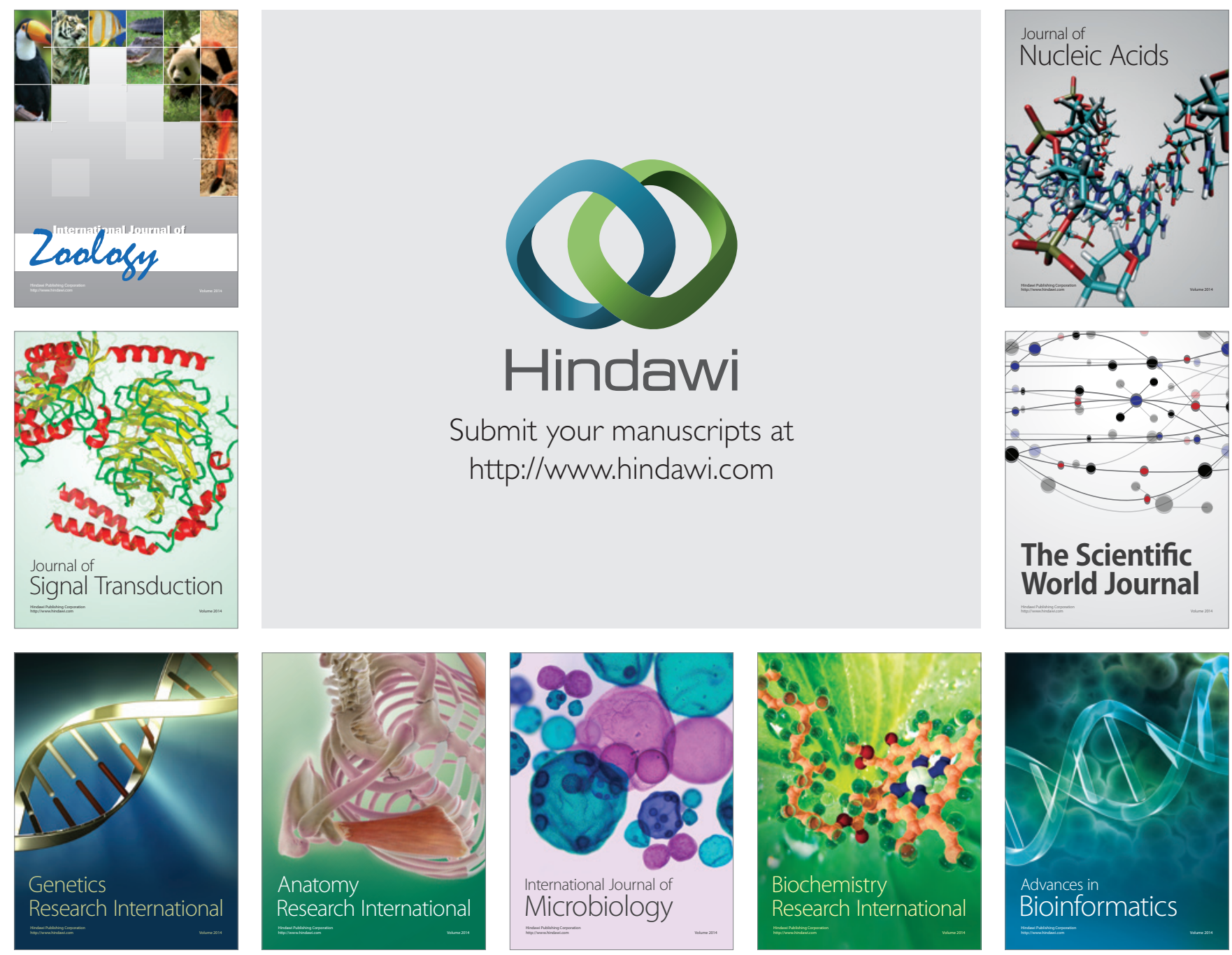

The Scientific World Journal
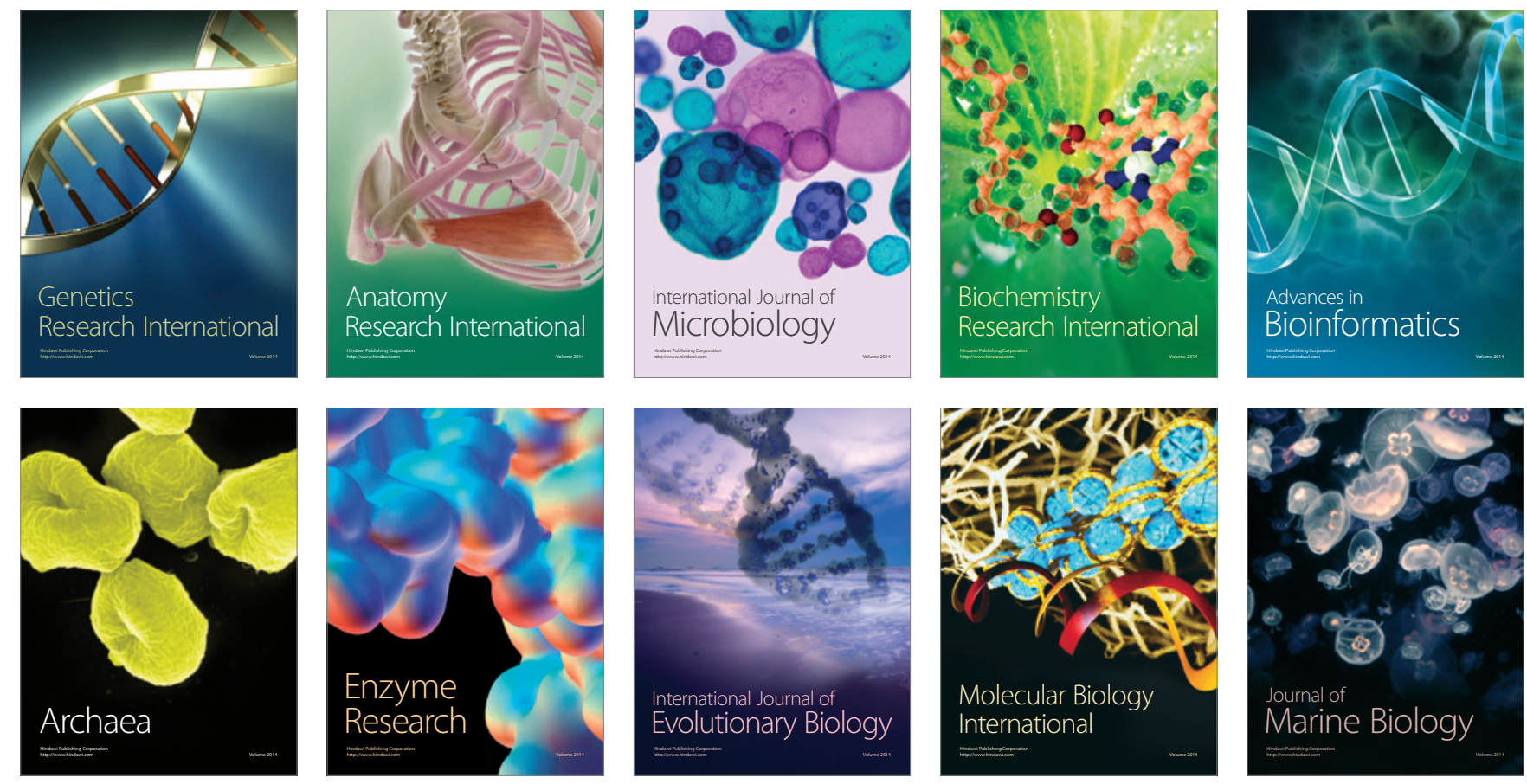